DOI: $10.22616 /$ j.balticsurveying.2018.004

\title{
THE CHANGE OF FOREST AREA IN ALYTUS AND VILNIUS COUNTIES (LITHUANIA)
}

\author{
Giedre Ivaviciute \\ Aleksandras Stulginskis University, Kaunas Forestry and Environmental Engineering \\ University of Applied Sciences, Klaipeda State University of Applied Sciences
}

\begin{abstract}
The article presents the analysis of the current situation of the forest area in Alytus and Vilnius counties. Comparative, analytical as well as statistical and logical analysis methods were used for the investigation. The aim of the investigation is to carry out the analysis of the Alytus and Vilnius counties forest area during the period between the years 2006 and 2018.

The object of the investigation - Alytus and Vilnius counties forest area. Tasks of the investigation: 1. To describe the status quo of forest in Alytus and Vilnius counties. 2. To analyze and compare the forest area change in Alytus and Vilnius counties during the period between the years 2006 and 2018.

The study found that forests prevailing in Alytus and Vilnius Counties are 50-59 years old. It was determined that pine trees prevail in Alytus County (71.05 percent) and in Vilnius County (16.38 percent) as well. The type of ownership prevailing in both Alytus and Vilnius counties is the forests of state significance managed by forest enterprises, national parks and state reserves. In Alytus County, during the period between the years 2006 and 2018, the forest area decreased by 4123.16 ha or 1.55 percent, in Vilnius County increased by 9593.16 ha or 2,35 percent.
\end{abstract}

Key words: forest area, forest coverage, the type of ownership.

\section{Introduction}

Article relevance. Knowing the status and changes in forests is essential for evaluating biodiversity dynamics and making effective conservation action plans. It is also essential knowledge for public awareness and policy (Wang et. al. 2015).

Forests are complex and renewable resources that fulfill many different roles. Above all, forests protect and co-create other natural resources. They shape the landscape, create recreational opportunities and deliver health benefits for humans (Zrobek-Rozanska et. al., 2014).

Humans rely on healthy forests to supply energy, building materials, and food and to provide services such as storing carbon, hosting biodiversity, and regulating climate. Defining forest health integrates utilitarian and ecosystem measures of forest condition and function, implemented across a range of spatial scales (Trumbore et. al. 2015).

Forests influence local and global temperatures and the flow of heat (Morris et. al., 2017).

Forest change has broad implications for climate, ecology, hydrology and human wellbeing. Numerous observational and modeling studies have shown that deforestation and afforestation have significant impacts on climate through their direct biophysical effects and indirect effects on the carbon cycle (Li et. al., 2017). From logging, agricultural production and other economic activities, deforestation adds more atmospheric $\mathrm{CO} 2$ than the sum total of cars and trucks on the world's roads (Sustainability..., 2018). Therefore, Regional quantification of feasibility and effectiveness of forest strategies to mitigate climate change should integrate observations and mechanistic ecosystem process models with future climate, $\mathrm{CO}_{2}$, disturbances from fire, and management (Law et.al., 2018).

It is known that climate change can affect forests by altering the frequency, intensity, duration, and timing of fire, drought, introduced species, insect and pathogen outbreaks, hurricanes, windstorms, ice storms, or landslides (Dale et. al., 2001). Climate change affects forests and their functioning directly, including key aspects such as net productivity, via altered abiotic conditions (Morin et. al., 2018).

Problem. Quantification of global forest change has been lacking despite the recognized importance of forest ecosystem services (Potapov et. al., 2013).

Although the forest area in the European Union is increasing, but global forest area changes are negative, it is therefore important to monitor the current state of forests and anticipate emerging threats. It has been established that due to anthropogenic or other activities, forests can degrade or 
disappear. Forest degradation and deforestation are distinctly different processes. While deforestation involves the conversion of forests to another land cover types, degradation results when forests remain forests but lose their ability to provide ecosystem services or suffer major changes in species composition due to overexploitation, exotic species invasion, pollution, fires, or other factors (Sasaki N., 2009).

Historical baselines of forest cover are needed to understand the causes and consequences of recent changes and to assess the effectiveness of land-use policies (Kim et. al., 2014).

The human approach to the forest has changed in different periods. In ancient times, the woods were inhabited by humans, they were a source of survival as well as hunting areas. Later, when people began to engage in agriculture, the forest became an obstacle to agricultural development. Intensive deforestation began. Some European countries (the Netherlands, Ireland, the United Kingdom, Denmark), with their rapid development of agriculture, almost eliminated their forests. It did not beat Lithuania either.

At present, the most wooded countries in the European Union are Finland (73\% of the total area), Sweden (69\%), Slovenia (62\%) and Latvia (54\%). The forests of six Member States (Spain, Poland, France, Finland, Sweden and Germany) cover two thirds of Europe's forest area. A large variety of EU forest types reflects its climate diversity (northern forests, alpine coniferous forests, etc.). Their distribution, in particular, depends on climate, soil, altitude and topographic conditions. Only 4 percent of forest areas have not been changed by human activity; 8 percent are plantations, and all others belong to the "semi-natural" forest category, i.e. are formed by humans. By the way, European forests are mostly owned by private individuals (about 60\% of the area), $40 \%$ are state forests (Ragonnaud, 2016).

Lithuanian forest resources are more numerous than those in Hungary, Slovakia, Croatia, Slovenia, and Switzerland. The forest area of the Republic of Lithuania is 3 to 6 times higher than in Albania, Ireland, Belgium, Denmark, Montenegro and the Netherlands.

According to the data of 2018, forests occupy 2167497.97 hectares in the Republic of Lithuania, and the country's forest coverage -33.20 percent. The most forested are Alytus (48.38\%), Vilnius (43.03 $\%$ ), Telšiai (36.25\%), Utena (35.12\%), and Tauragè (33.34 percent) counties (Nacionaline zemes..., 2006-2018).

The object of the investigation - Alytus and Vilnius counties forest area.

The aim of the investigation. To carry out the analysis of the Alytus and Vilnius counties forest area during the period between the years 2006 and 2018.

Tasks of the investigation:

1. To describe the status quo of forest in Alytus and Vilnius counties.

2. To analyze and compare the forest area change in Alytus and Vilnius counties during the period between the years 2006 and 2018.

\section{Methodology of research and materials}

Comparative, analytical as well as statistical and logical analysis methods were used for the investigation.

The article analyses work of foreign and Lithuanian scientists, published in scientific publications, conferences.

The land fund statistics of the Republic of Lithuania (Nacionaline zemes..., 2006-2018), graphically depicted in figures, were used for the fulfilment of the research of the change of damaged land in Alytus and Vilnius counties for the years 2006 - 2018.

The article analyzed and assessed the current state of the forest in the counties of Alytus and Vilnius, i.e. the prevailing tree species and age were determined, the distribution of forests by groups and ownership type was investigated.

The study provides the forest area change analysis in Alytus and Vilnius Counties. The 13 year period, i.e. the period between the years 2006 and 2018, was selected for the determination of the change. Statistics data were systematized, analyzed and expression of the percentage was calculated during the preparation of the research. 


\section{Discussion and results}

In Alytus County forests in 2018 occupied the area of 262134.81 ha, i.e. 48.38 percent of the entire area of the county (Nacionaline zemes..., 2006-2018).

The largest part of the growing forests consists of forests 50-59 years old, they make up 16.89 percent, 60-69 years old forests make up 12.43 percent, 100 years old - 6.35 percent. Pine (71.05 percent) trees prevail in the Alytus County forests.

In the County, there mostly is Group IV or commercial forests (59.89 percent). Group I forests include forest reserves that make up 7.02 percent.

Analyzing data by type of ownership, state enterprises, national parks and state-owned forests managed by state reserves make up the largest part, i.e. 43.85 percent, private and other forests 32.52 percent, and forests for restoration of ownership rights -22.98 percent. The municipal forests of state significance make up 0.38 percent, forests of state significance managed by the Ministry of Transport and Communications make up 0.12 percent, non-state-owned areas managed by the Ministry of Transport and Communications make up 0.01 percent (Intelektuali..., 2018).

In the Vilnius County, forests make up even $43.03 \%$, it is the second one after Alytus County, the woodiness of which is extremely high and exceeds $40 \%$. In the county in 2018 , forests occupied 418658.45 hectares.

The prevailing tree species in the forest landscape are pine, which form 52.30 percent, as well as birch (15.15 percent) and fir trees (14.59 percent). Growing forests mainly are 50-59 years old (16.38 percent), 60-69 years old (13.61 percent) and 40-49 years old (12.02 percent).

Distribution of forests in Vilnius County by forest groups: Group I forest reserves - 0.38 percent, Group II special-purpose forests - 16.30 percent, Group III protective forests - 15.77 percent, Group IV commercial forests -67.55 percent.

According to the type of ownership, the forests are divided into the following: forests of state significance owned by forest enterprises, national parks and state reserves make up $49.33 \%$, forests intended for the restoration of ownership rights $-25.05 \%$, private and other forests $-23.15 \%$, forests of state significance owned by municipalities make up 1.37 percent, state forests belonging to the Ministry of National Defense and the Ministry of the Interior - 0.58 percent, forests of state importance managed by other legal entities -0.23 percent, forests of state significance managed by the Ministry of Transport and Communications -0.15 percent, forests managed by forest enterprises and proposed to be included into the areas belonging to the Ministry of the Interior make up $0.08 \%$, forests of state significance proposed to be excluded from the areas belonging to the Ministry of the Interior make up $0.02 \%$, non-state-owned areas belonging to municipalities $-0.01 \%$, non-state-owned areas managed by forest enterprises -0.01 percent (Intelektuali..., 2018).

In Alytus County during the period between the years 2006 and 2018 the forest area decreased by 4123.16 ha or 1.55 percent and in 2018 occupied 262134.81 ha (Fig. 1).

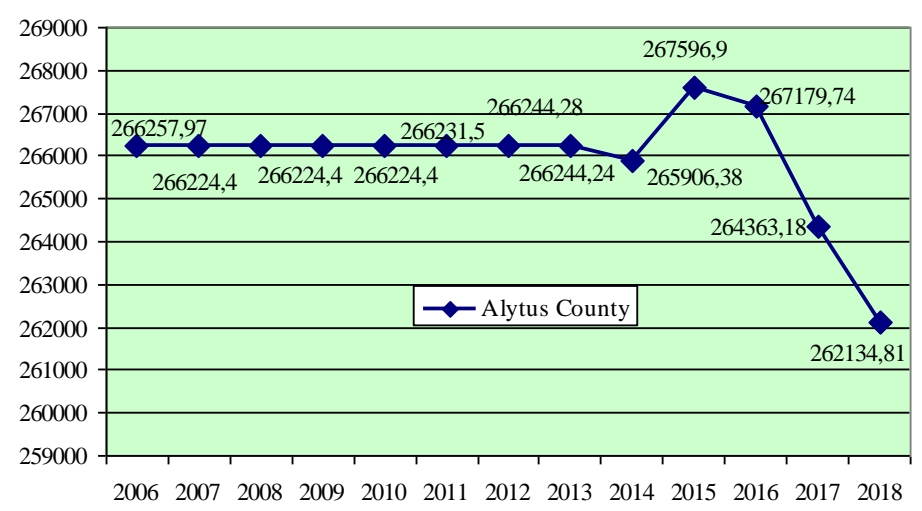

Fig. 1. Forest area change in Alytus County in ha during the years 2006-2018

The largest part of Alytus County forests is made up by forests growing in the municipality of Varèna district, which in 2018 occupied 148870.35 ha. The smallest forest area was noticed in Alytus city municipality (1192.48 ha). 
During the period under review, forest areas in all municipalities increased, except for the Alytus municipality, in which forests fell by 60.22 ha or 4.81 percent and Varena district municipality (4432.22 or 2.89 percent). Lazdijai district municipality has the largest forest development, the area has increased by 206.01 ha or 0,45 percent.

In Vilnius County during the analyzed period the forest area increased by 9593.16 ha or 2,35 percent. (Fig. 2).

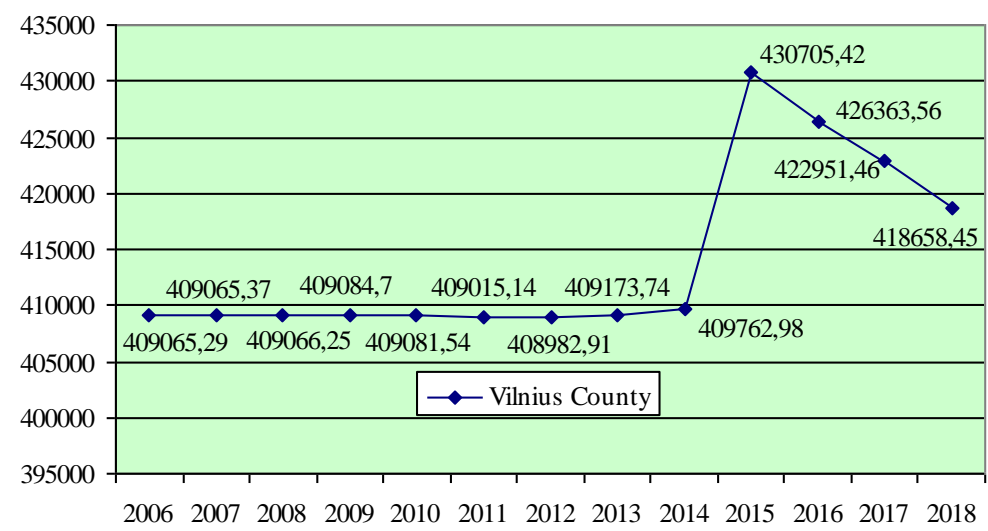

Fig. 2. Forest area change in Vilnius County in ha during the years 2006-2018

The largest forest area in 2018 was in Švenčionys district (97103.76 ha), the smallest - in the city of Vilnius (14348.83 ha).

During the years 2006-2018, forest areas in all municipalities increased, except for the Elektrenai municipality, in which forests fell by 294.21 ha or 1.71 percent.

During the period between the years 2006 and 2018, the largest development took place in the district of Vilnius ( 3476.08 ha or 4.12 percent).

After the analysis of the change of the forests in the most wooded counties of the Republic of Lithuania in 2006-2018, it has been established that forests in Alytus County decreased by 4123.16 ha or $1.55 \%$, however, the area under study in Vilnius County increased by 9593.16 ha or $2.35 \%$.

During the period between the years 2006-2018 the forest area of the Republic of Lithuania increased by 67156.33 ha or $3.20 \%$.

Tendencies. According to the data of the National Land Service under the Ministry of Agriculture, in 2018 in Alytus County there were 3112.32 hectares of unused land and land unfit for agriculture, of which 2516.84 hectares were not used for agriculture and 595.48 ha hectares of damaged land. In Vilnius County there were 11476.88 hectares of unused land and land unfit for agriculture. After afforestation of this land, Alytus county's forest coverage would increase by about 1.17 percent and will occupy $265,247.72$ hectares and make up 48.96 percent. Vilnius county's forest coverage would increase and will occupy 430135.33 hectares and make up 44.21 percent.

The forest area was increasing due to the implementation of the forest improvement program, the promotion of plantation forests, the promotion of self-help to forest regeneration, participation in the Rural Development Program, and EU payments for this.

Forests are not static. Their structure and composition are constantly changing, different types of trees in the forests are germinating, growing and dying. The change in the forests is caused by a variety of natural causes, which are usually understood as "damaging" or "destroying" forests, as well as human anthropogenic activities. The socio-economic significance of forests is weighty, but not all of the countries appreciate their benefits.

Forests are lungs of our planet, which is why it is necessary to stop forest cutting, destruction and to carry out reforestation programs and projects.

\section{Conclusions}

1. After examining the forests according to their age, it was obtained that forests prevailing in Alytus and Vilnius Counties are 50-59 years old. 
2. After analyzing the prevailing species of trees, it was determined that pine trees prevail in Alytus County (71.05 percent) and in Vilnius County (16.38 percent) as well.

3. The type of ownership prevailing in both Alytus (43.85 percent) and Vilnius (49.33) counties is the forests of state significance managed by forest enterprises, national parks and state reserves.

4. In Alytus County during the period between the years 2006 and 2018 the forest area decreased by 4123.16 ha or 1.55 percent, in Vilnius County increased by 9593.16 ha or 2,35 percent.

5. After afforestation hectares of unused land and land unfit for agriculture, it is a possibility to increase forest coverage in Alytus (from 48.38 to 48.96 percent) and Vilnius (from 43.03 to 44.21 percent) County.

\section{References}

1. Dale H.V., Joyce L.A., McNulty S. Neilson R.P., Ayres M.P., Flannigan M.D., Hanson P.J., Irland L.C., Lugo A.E., Peterson CH.J., Simberloff D., Swanson F.J. Stocks B.J., Wotton B.M. (2001). Climat Change and Forest Disturbances. BioScience. P. 723-734.

2. Intelektuali miškų ūkio elektroninių paslaugų informacinè sistema. Viewed 10 June, 2018. (https://www.valstybiniaimiskai.lt/lt/MiskuBukle/Apskritys/Puslapiai/Alytausapskritis.aspx).

3. Kim D.H., Sexton J., Noojipady P., Huang Ch., Anand A., Channan S., Feng M., Townshend J. (2014). Global, Landsat-based forest-cover change from 1990 to 2000. Remote Sensing of Environment. Volume 155. P. 178-193).

4. Law B.E., Hudiburg T.W., Berner L.T., Kent J. J., Buotte P. C., Harmon M.E. (2018). Land use strategies to mitigate climate change in carbon dense temperate forests. Proceedings of the National Academy of Sciences of the United States of America. P.1-6.

5. Li Y., Sulla-Menashe D., Motesharrei S., Song X.P., Kalnay E., Ying Q., Li Sh., Ma Z. (2017). Inconsistent estimates of forest cover change in China between 2000 and 2013 from multiple datasets: differences in parameters, spatial resolution, and definitions. Scientific Reports. Volume 7.

6. Morin X., Fahse L., Jactel H., Scherer-Lorenzen M., Garcia - Valdes R., Bugmann H. (2018). Long - term response of forest productivity to climate change is mostly driven by change in tree species composition. Scientific Reports 8. P. 1-12.

7. Morris E., Locatelli B., Sheil D., Cohen J., Murdiyarso D., Gutierrez V., van Noordwijk M., Creed I..F., Pokorny J., Gaveau D., Spracklen D.V., Tobella A.B., Ilstedt U., Teuling A.J., Gebrehiwot S.G., Sands D.C., Muys B., Sullivan C.A. (2017). Trees, forests and water: Cool insights for a hot world. Global Environmental Change. Volume 43. P. 51-61.

8. Nacionalinè žemès tarnyba prie Žemès ūkio ministerijos. Lietuvos Respublikos žemés fondas. Vilnius, 20062018. -144 p.

9. Potapov P.V., Moore R., Hancher M., Turubanova S.A., Tyukavina A., Thau D., Stehman S.V., Goetz S.J., Loveland T.R., Kommareddy A., Egorov., A., Chini L., Justice C.O., Townshend J. R. (2013). Highresolution global maps of 21st-century forest cover change. Science. Volume 342, Issue 6160. P. 850-853.

10. Ragonnaud G. (2016). Europe Union and Forests. 2016/9.

11. Sasaki N. (2009). Critical need for new definitions of "forest" and "forest degradation" in global climate change agreements. Conservation Letters. A journal of the Society for Conservation Biology. Volume 2, Issue 5. (https://doi.org/10.1111/j.1755-263X.2009.00067.x).

12. Sustainability American. Deforestation and Its Extreme Effect on Global Warming. Viewed 19 June, 2018, (https://www.scientificamerican.com/article/deforestation-and-global-warming/).

13. Trumbore S., Brando P, Hartmann. (2015). Forest health and global change. Science. Volume 349, Issue 6250. P. 814-818.

14. Wang H., Lu Z., Gu L., Wen CH. (2015). Observations of China's forest change (2000-2013) based on Global Forest Watsch dataset. Biodiversity Science. Volume 23, Issue 5. P. 575-582.

15. Zrobek-Rozanska A., Nowak A., Nowak M., Zrobek S. (2014). Financial Dilemmas Associated with the Afforestation of Low-Productivity Farmland in Poland. Forest 2014, 5(11). P. 2846-2864.

\section{Information about author}

Giedrè Ivavičiūtė, Lecturer, Institute of Land Use Planning and Geomatics, Water and Land Management faculty, Aleksandras Stulginskis University. Address: Universiteto g. 10, LT - 53361 Akademija, Kauno raj., Lithuania. Tel. 8 - 377523 72, e-mail: ivavice@ gmail.com . Fields of interest: landscape architecture. Lecturer, Kaunas Forestry and Environmental Engineering University of Applied Sciences. Address: Liepų st. 1, Girionys, LT -53101, Kauno raj. Lithuania. e-mail: ivavice@ gmail.com.

Lecturer, Klaipeda State University of Applied Sciences. Address: Jaunystès st. 1, LT-91274, Klaipėda, Lithuania. e-mail: ivavice@gmail.com . 